Doi: HTTPS://DOI.ORG/10.23910/IJBSM/2017.8.1.1736

\title{
Impact of Different Sources of Nutrients on Growth and Yield Attributes of Groundnut (Arachis hypogaea L.)
}

\author{
Rajesh Chaudhri ${ }^{1}$, Roshan Choudhary ${ }^{2}$ and R. S. Choudhary ${ }^{3^{*}}$ \\ ${ }^{1}$ SKN College of Agriculture, SKN University of Agriculture, Jobner, Jaipur, Rajasthan (303 328), India \\ ${ }^{2 \& 3}$ Dept. of Agronomy, Rajasthan College of AMPU of Agriculture \& Technology, Udaipur, Rajasthan (313 001), India
}

\author{
Corresponding Author \\ R. S. Choudhary \\ e-mail: agroudr2013@gmail.com
}

\author{
Article History \\ Manuscript No. AR1736 \\ Received in $20^{\text {th }}$ Nov, 2016 \\ Received in revised form $30^{\text {th }}$ Jan, 2017 \\ Accepted in final form $6^{\text {th }}$ Feb, 2017
}

\begin{abstract}
Field experiment was conducted during kharif seasons of 2011 and 2012 at S.K.N. College of Agriculture, Jobner to study the effect of integrated nutrient management levels on growth parameters and yield of groundnut (Arachis hypogaea L.). Treatments consisted of the eight levels of organic manures and fertilizers in main plots [control, RDF ( $\left.25 \mathrm{~kg} \mathrm{~N}+45 \mathrm{~kg} \mathrm{P}_{2} \mathrm{O}_{5} \mathrm{~kg} \mathrm{ha}^{-1}\right), \mathrm{FYM} 15 \mathrm{t} \mathrm{ha}{ }^{-1}, \mathrm{FYM} 7.5 \mathrm{tha} \mathrm{F}^{-1}+1 / 2$ $\mathrm{RDF}$, poultry manure $6 \mathrm{t} \mathrm{ha}^{-1}$, poultry manure $3 \mathrm{t} \mathrm{ha}^{-1}+1 / 2 \mathrm{RDF}$, vermicompost $5 \mathrm{t}$ ha ${ }^{-1}$, and vermicompost $2.5 \mathrm{t}$ ha ${ }^{-1}+1 / 2 \mathrm{RDF}$ ] and four levels of iron in sub plots [0.0,5.0, 10.0 and $\left.15.0 \mathrm{~kg} \mathrm{ha}^{-1}\right]$ were compared. Poultry manure $3 \mathrm{t}+1 / 2$ RDF produced significant higher dry matter accumulation ( $65 \mathrm{~g} \mathrm{plant}^{-1}$ ), branches plant ${ }^{-1}$ (20.45), dry weight of nodules (109 g), leaf area index (5.62), no.of pods plant ${ }^{-1}$ (24.37), no. of kernels pod ${ }^{-1}(1.88)$, pod yield $\left(2863 \mathrm{~kg} \mathrm{ha}^{-1}\right)$ and stover yield $\left(4365 \mathrm{~kg} \mathrm{ha}^{-1}\right)$ of groundnut at harvest over rest of the treatments during both the years of study. Iron levels up to $10 \mathrm{~kg} \mathrm{ha}^{-1}$ also significantly increased the dry matter accumulation ( $\left.59.8 \mathrm{~g} \mathrm{plant}^{-1}\right)$, branches plant ${ }^{-1}$ (19.08), dry weight of nodules (104.9 g), leaf area index (5.74), no. of pods plant ${ }^{-1}$ (21.30), no. of kernels pod ${ }^{-1}$ (1.61), pod yield (2461 kg $\mathrm{ha}^{-1}$ ) and stover yield ( $3868 \mathrm{~kg} \mathrm{ha}^{-1}$ ) of groundnut over control and $5.0 \mathrm{~kg} \mathrm{Fe} \mathrm{ha}^{-1}$ but was found at par with $15 \mathrm{~kg} \mathrm{Fe}^{-1}$ during both the years of study on pooled basis. However, poultry manure $3 \mathrm{t}+1 / 2$ RDF proved significantly superior over other treatments in respect growth and yield attributes of groundnut.
\end{abstract}

Keywords: Groundnut, FYM, poultry manure, vermicompost, iron, yield

\section{Introduction}

Groundnut or peanut (Arachis hypogaea L.) is also known as a 'King' of oilseed (Priya et al., 2013) belongs to family Fabaceae. Groundnut (Arachis hypogaea L.) is an important oilseed crop and foodgrain legume crop of India. In 2011-12, it was cultivated in an area of 5.26 mha with production of $6.96 \mathrm{mt}$ (DAC, 2013).. It contains about 40-45\% oil, $20-25 \%$ protein, $20.5 \%$ carbohydrate, $5 \%$ fibre and ash and makes a sustainable contribution to human nutrition. Now a days, use of chemical fertilizer is increasing to boost up crop production to meet the need for ever increasing population of the nation. Simultaneously cost of chemical fertilizer has been increasing constantly, besides these; use of inorganic fertilizer alone is injurious to soil and environmental health. Thus combined use of inorganic fertilizer with organic fertilizers enhances crop production and sustains soil fertility (Gupta et al., 2003).

Groundnut is highly responsive to fertilizer application, although groundnut being a legume is capable of fixing atmospheric nitrogen. Application of higher dose of nitrogen may reduce nodule number and nodule growth and thus adversely affects the nitrogen fixation capacity (Veeramani et al., 2012). The optimization of the mineral nutrition has key role in optimizing the production of groundnut because it has very high nutrient requirement. On contrary groundnut farmers use very less fertilizer resulting in severe mineral nutrient deficiencies due to inadequate and imbalance use of nutrients is one of the major factors responsible for low yield in groundnut (Veermani \& Subrahmaniyan, 2011). Thus it is high time to look into the mineral nutrition aspects of groundnut for achieving high yield and advocate the suitable package of practices for optimization of yield (Singh, 2004). Keeping in view the above facts, the present investigation was aimed to maximize the yield in groundnut through different nutrient management practices.

\section{Materials and Methods}

The field experiment was conducted during kharif seasons of 2011 and 2012 at S.K.N. College of Agriculture, Jobner. In this, spreading type groundnut ' $\mathrm{M}-13$ ' was sown at $45 \times 10$ 
$\mathrm{cm}^{2}$ spacing using a seed rate of $80 \mathrm{~kg} \mathrm{ha}^{-1}$ on $8^{\text {th }}$ July, 2011 and $9^{\text {th }}$ July, 2012 and was harvested on $3^{\text {rd }}$ November, 2011 and $4^{\text {th }}$ November, 2012, respectively. The site was situated at latitude of $26^{\circ} 05^{\prime} \mathrm{N}$, longitude of $75^{\circ} 28^{\prime} \mathrm{E}$ and at an altitude of $427 \mathrm{~m}$ amsl. This region falls under agro-climatic zone III-A (Semi-Arid Eastern Plain Zone) of Rajasthan. The soil of the experimental field was loamy sand, low in organic carbon ( 0.13 and $0.15 \%$ ) as analyzed by Walkley and Black's rapid titration method (Jackson, 1973), available nitrogen (130.3 and $130.7 \mathrm{~kg} \mathrm{ha}^{-1}$ ) by alkaline permanganate method (Subbiah and Asija, 1956), phosphorus (16.5 and $16.5 \mathrm{~kg}$ ha $^{-1}$ ) by Olsen's method (Olsen et al., 1954) and iron (2.2 and $2.4 \mathrm{mg} \mathrm{kg}^{-1}$ ) by Lindsay and Norvell (1978) but medium in potassium content (175.2 and 175.3) as analyzed by Flame photometer method (Metson, 1956) and alkaline in reaction (8.2). The experiment was evaluated in a split plot design, allocating organic manures and fertilizer in main plots and iron in sub plots and replicated three times. The treatments consisted of eight organic manures and fertilizer levels viz., control, RDF $25 \mathrm{~kg} \mathrm{~N}+45 \mathrm{~kg} \mathrm{P}_{2} \mathrm{O}_{5} \mathrm{~kg} \mathrm{ha}^{-1}$, FYM $15 \mathrm{t} \mathrm{ha}^{-1}$, FYM $7.5 \mathrm{t} \mathrm{ha}^{-1}+1 / 2 \mathrm{RDF}$, poultry manure $6 \mathrm{t} \mathrm{ha}^{-1}$, poultry manure $3 \mathrm{t}$ ha $^{-1}+1 / 2$ RDF, Vermicompost $5 \mathrm{t} \mathrm{ha}^{-1}$, Vermicompost $2.5 \mathrm{t} \mathrm{ha}^{-1}+1 / 2$ RDF and four iron levels viz., 0.0, 5.0, 10.0 and $15.0 \mathrm{~kg} \mathrm{ha}^{-1}$. Different sources of nutrients viz., FYM (N-0.42\%, P-0.25\% and $\mathrm{K}-0.47 \%$ during 2011 and $\mathrm{N}-0.45 \%, \mathrm{P}-0.22 \%$ and $\mathrm{K}-0.50 \%$ during 2012), poultry manure ( $\mathrm{N}-1.25 \%, \mathrm{P}-1.05 \%$ and $\mathrm{K}-0.80 \%$ during 2011 and $\mathrm{N}-1.37 \%, \mathrm{P}-1.15 \%$ and $\mathrm{K}-0.86 \%$ during 2012 ) and vermicompost ( $\mathrm{N}-1.76 \%, \mathrm{P}-1.45 \%$ and $\mathrm{K}-0.95 \%$ during 2011 and $\mathrm{N}-1.85 \%, \mathrm{P}-1.64 \%$ and $\mathrm{K}-1.06 \%$ during 2012) were incorporated into the soil i.e. 21 days before sowing based on soil test. Iron was applied at the sowing time as per treatment through $\mathrm{FeSO}_{4}$. The seed treatment was done with bavistin 2 $\mathrm{g} \mathrm{kg}^{-1}$ followed by Rhizobium culture as per treatments. The amount of rainfall during the crop growth period was 281.6 $\mathrm{mm}$ and $533.6 \mathrm{~mm}$ in 2011 and 2012, respectively. Nutrient content in plant samples were analyzed as per procedure suggested by Snell and Snell (1959). The data were statistically analyzed as procedure given by Gomez and Gomez (1989) and presented on pooled basis for both the years of study.

\section{Results and Discussion}

\subsection{Growth parameters}

All the organic, inorganic sources of nutrients were significantly increased the growth attributes of groundnut. Data (Table 1) indicated that plant height of groundnut was significantly increased by different sources of nutrients. Increase in plant height was more pronounced at 70 and 105 DAS and at harvest. Application of vermicompost $2.5 t+1 / 2$ RDF recorded the highest plant height and proved superior to control and FYM 15 t at 70, 105 DAS and at harvest. Results showed that dry matter accumulation and branches per plant (Table 1) did not influenced by manures and fertilizers upto 35 DAS but at later stages, the effect was observed significant.
Application of poultry manure $3 t+1 / 2$ RDF produced the highest dry matter accumulation and branches per plant and remained at par with vermicompost $2.5 \mathrm{t}+1 / 2 \mathrm{RDF}$ while recorded the increase of $30.8,18.8,18.2,18.0,8.9$ and $8.5 \%$ over control in case of dry matter accumulation whereas branches plant ${ }^{-1}$ represented an increase of 30.9, 18.5, 14.6, 14.1, 6.6 and 6.5\% over control. Application of integrated use of manures and fertilizer had consistent effect on all the growth parameters. Higher plant height was observed in different treatments due to the favorable effect of organic manure on growth on account of improved photo-synthetically active leaf area for longer period during vegetative and reproductive phase led to more absorption and utilization of radiant energy which ultimately resulted in higher plant height.

A perusal of data (Table 1) indicated that the increase in dry weight of nodules due to application of different sources of nutrients resulted that poultry manure $3 \mathrm{t}+1 / 2$ RDF was found to the tune of $15.6,15.0,8.9,8.2,7.7,7.0$ and $6.8 \%$ higher over control on pooled mean basis. The increased value in growth characters might be due to the combined effect of organic and inorganic fertilizers on the increased nutrient availability and microbial activity resulting in better nutrient absorption and growth of crops. The increased growth in terms of plant height, branches plant ${ }^{-1}$, expansion of leaf lamina and chlorophyll content provided greater sites for photosynthesis and diversion of photosynthates towards sink (Akbari et al., 2011).

The highest leaf area index (Table 1 ) was recorded with application of vermicompost $2.5 \mathrm{t}+1 / 2 \mathrm{RDF}$ and being at par with poultry manure $3 t+1 / 2 R D F, F Y M 7.5 t+1 / 2 R D F, R D F(25 \mathrm{~kg} \mathrm{~N}$ and $45 \mathrm{~kg} \mathrm{P}_{2} \mathrm{O}_{5}$ ), poultry manure $6 \mathrm{t}$ and vermicompost $5 \mathrm{t}$. Plant height, dry matter accumulation, and branches plant ${ }^{-1}$, dry weight of nodules were significantly increased (Table 1) with application of $10 \mathrm{~kg} \mathrm{Fe} \mathrm{ha}^{-1}$ over $5 \mathrm{~kg} \mathrm{Fe} \mathrm{ha}^{-1}$ and control and statistically remained at par with $15 \mathrm{~kg} \mathrm{Fe} \mathrm{ha}^{-1}$ at 70, 105 DAS and at harvest. It is inferred that application of $15 \mathrm{~kg} \mathrm{Fe} \mathrm{ha}^{-1}$ recorded the significantly highest LAI and chlorophyll content over control and $5 \mathrm{~kg} \mathrm{Fe} \mathrm{ha}^{-1}$ while it was found at par with $10 \mathrm{~kg} \mathrm{Fe} \mathrm{ha}^{-1}$ on pooled mean basis (Table 1). The magnitude of increase in LAl was 17.7 and $7.1 \%$ over control and $5 \mathrm{~kg}$ $\mathrm{Fe} \mathrm{ha}^{-1}$, respectively and in chlorophyll content increase was 11.3 and $6.2 \%$ over control and $5 \mathrm{~kg} \mathrm{Fe} \mathrm{ha}^{-1}$, respectively. The favorable influence of applied Fe on these characters may be due to its catalytic or stimulatory effect on most of the physiological and metabolic processes of plant. Application of Fe might have increased the availability and steady supply of nutrients for plant metabolism and photosynthetic activity resulting into optimum growth and development of the crop. The results are in conformity with the findings of Sumathi and Rao (2007). The overall growth of plant increased in terms of plant height and leaf area which contributed for higher dry matter production (Malligawad, 2010). This might be due to readily available Fe at early and the critical stage of plant growth that facilitated maximum plant growth. 
Table 1: Effect of sources of organic manures and fertilizers under varying levels of iron on growth parameters and yield of groundnut (Pooled)

\begin{tabular}{|c|c|c|c|c|c|c|c|c|c|c|c|c|c|c|c|c|}
\hline \multirow[t]{2}{*}{ Treatments } & \multicolumn{3}{|c|}{ Plant height $(\mathrm{cm})$} & \multicolumn{3}{|c|}{ DMC (g plant ${ }^{-1}$ ) } & \multicolumn{3}{|c|}{ Branches plant ${ }^{-1}$} & \multirow{2}{*}{$\begin{array}{l}\text { WDN } \\
\text { (g) }\end{array}$} & \multirow[t]{2}{*}{ LAI } & \multirow{2}{*}{$\begin{array}{l}\mathrm{CC} \\
(\mathrm{mg} \\
\left.\mathrm{g}^{-1}\right)\end{array}$} & \multirow[t]{2}{*}{ NPP } & \multirow{2}{*}{$\begin{array}{l}\mathrm{NK} \\
\mathrm{PH}\end{array}$} & \multirow{2}{*}{$\begin{array}{c}\text { PY } \\
(\mathrm{kg} \\
\left.\mathrm{ha}{ }^{-1}\right)\end{array}$} & \multirow{2}{*}{$\begin{array}{c}\text { SY (kg } \\
\left.\mathrm{ha}^{-1}\right)\end{array}$} \\
\hline & $\begin{array}{c}70 \\
\text { DAS }\end{array}$ & $\begin{array}{l}105 \\
\text { DAS }\end{array}$ & AV & $\begin{array}{c}70 \\
\text { DAS }\end{array}$ & $\begin{array}{l}105 \\
\text { DAS }\end{array}$ & AV & $\begin{array}{c}70 \\
\text { DAS }\end{array}$ & $\begin{array}{l}105 \\
\text { DAS }\end{array}$ & AV & & & & & & & \\
\hline \multicolumn{17}{|c|}{ Manures and fertilizers } \\
\hline Control & 10.5 & 14.0 & 18.8 & 18.6 & 27.5 & 49.7 & 6.27 & 11.40 & 15.62 & 94.3 & 5.06 & 0.58 & 12.70 & 0.94 & 1806 & 3185 \\
\hline $\begin{array}{l}\text { RDF }(25 \mathrm{~kg} \\
\mathrm{N} \& 45 \mathrm{~kg} \\
\left.\mathrm{P}_{2} \mathrm{O}_{5}\right)\end{array}$ & 12.6 & 16.0 & 21.1 & 21.6 & 30.6 & 55.0 & 7.23 & 13.32 & 17.93 & 101.2 & 5.56 & 0.68 & 18.33 & 1.30 & 2193 & 3570 \\
\hline FYM 15 t & 12.3 & 15.8 & 20.8 & 21.3 & 30.4 & 54.7 & 7.13 & 12.85 & 17.26 & 100.1 & 5.50 & 0.65 & 15.85 & 1.08 & 2026 & 3361 \\
\hline $\begin{array}{l}\text { FYM } 7.5 \mathrm{t} \\
+1 / 2 \text { RDF }\end{array}$ & 12.7 & 16.1 & 21.3 & 21.6 & 30.7 & 55.1 & 7.20 & 13.25 & 17.85 & 100.7 & 5.56 & 0.65 & 17.95 & 1.24 & 2185 & 3518 \\
\hline $\begin{array}{l}\text { Poultry } \\
\text { manure } 6 \mathrm{t}\end{array}$ & 13.0 & 16.5 & 21.7 & 23.8 & 33.6 & 59.9 & 8.19 & 14.29 & & 102.1 & 5.59 & 0.66 & & 1.54 & 2421 & 3785 \\
\hline $\begin{array}{l}\text { Poultry ma- } \\
\text { nure } 3 t+1 / 2 \\
\text { RDF }\end{array}$ & 13.2 & 16.7 & 21.8 & 26.0 & 36.9 & 65.0 & 9.10 & 15.33 & 20.45 & 109.0 & 5.62 & 0.69 & & 1.88 & 2863 & 4365 \\
\hline $\begin{array}{l}\text { Vermicom- } \\
\text { post } 5 \mathrm{t}\end{array}$ & 12.9 & 16.3 & 21.5 & 23.8 & 33.6 & 59.7 & 8.17 & 14.21 & 19.19 & 101.9 & 5.51 & 0.67 & & 1.60 & 2427 & 3785 \\
\hline $\begin{array}{l}\text { Vermicom- } \\
\text { post } 2.5 \\
t+1 / 2 \text { RDF }\end{array}$ & 13.3 & 16.9 & 21.9 & 25.8 & 36.6 & 64.8 & 9.07 & 15.26 & 20.39 & 108.5 & 5.63 & 0.69 & 23.54 & 1.85 & 2810 & 4241 \\
\hline SEm \pm & 0.24 & 0.30 & 0.34 & 0.44 & 0.63 & 1.04 & 0.16 & 0.16 & 0.26 & 1.28 & 0.07 & 0.01 & 0.41 & 0.03 & 51 & 88.38 \\
\hline $\operatorname{CD}(p=0.05)$ & 0.71 & 0.87 & 0.98 & 1.29 & 1.83 & 3.00 & 0.47 & 0.45 & 0.76 & 3.72 & 0.20 & 0.04 & 1.18 & 0.09 & 147 & 255.97 \\
\hline \multicolumn{17}{|l|}{$\mathrm{Fe}\left(\mathrm{kg} \mathrm{ha}^{-1}\right)$} \\
\hline 0 & 11.0 & 14.8 & 19.6 & 20.9 & 29.9 & 54.0 & 6.99 & 12.87 & 17.33 & 96.8 & 4.97 & 0.62 & 15.21 & 1.12 & 2038 & 3456 \\
\hline 5 & 12.3 & 15.9 & 20.9 & 22.4 & 32.0 & 57.1 & 7.69 & 13.62 & 18.29 & 101.1 & 5.46 & 0.65 & 18.47 & 1.34 & 2329 & 3636 \\
\hline 10 & 13.4 & 16.7 & 21.8 & 23.9 & 33.5 & 59.8 & 8.18 & 14.16 & 19.08 & 104.9 & 5.74 & 0.68 & 21.30 & 1.61 & 2461 & 3868 \\
\hline 15 & 13.7 & 17.0 & 22.2 & 24.1 & 34.6 & 61.1 & 8.32 & 14.32 & 19.27 & 106.0 & 5.85 & 0.69 & 21.77 & 1.65 & 2538 & 3946 \\
\hline SEm \pm & 0.15 & 0.20 & 0.22 & 0.33 & 0.45 & 0.78 & 0.11 & 0.12 & 0.21 & 0.97 & 0.05 & 0.01 & 0.28 & 0.02 & 34 & 52.64 \\
\hline $\operatorname{CD}(p=0.05)$ & 0.43 & 0.56 & 0.62 & 0.93 & 1.26 & 2.19 & 0.31 & 0.34 & 0.59 & 2.72 & 0.13 & 0.03 & 0.79 & 0.07 & 97 & 147.77 \\
\hline
\end{tabular}

DMC: Dry matter accumulation; AV: At harvest; DWN: Dry weight of nodules; LAI: Leaf area index; CC: Chlorophyll content; NPP: No.of pods plant ${ }^{-1}$; NKPH: No.of kernels pod ${ }^{-1}$ at harvest; PY: Pod yield; SY: Stover yield; FYM; Farm yard manure; RDF: Recommended dose of fertilizer; NS: non-significant

\subsection{Yield attributes}

A perusal of data (Table 1) showed that combined use of manures and fertilizers caused a significant effect on no. of pods plant ${ }^{-1}$, no. of kernels pod ${ }^{-1}$, pod and stover yield at harvest over their sole application and control wherein, significantly higher no. of pods plant ${ }^{-1}$ and number of kernels pod $^{-1}$ of groundnut were registered with application of poultry manure $3 t+1 / 2$ RDF being at par with vermicompost $2.5 t+1 / 2$ RDF and represented an increase of 91.9, 53.8, 35.8, 32.9, 19.7, and 19.5; and 100.0, 74.0, 51.6, 44.6, 22.0 and 17.5\% higher over control and rest of the treatments, respectively.
Simultaneously, application of poultry manure $3 t+1 / 2$ RDF being at par with vermicompost $2.5 t+1 / 2$ RDF and produced significantly higher pod and stover yield of groundnut and represented an increase of 58.6, 41.4, 31.1, 30.1, 18.2, and 17.9; and 37.0, 29.9, 24.1, 22.3, 15.3 and 15.3\% higher over control and rest of the treatments, respectively. No. of pods plant ${ }^{-1}$, number of kernels pod $^{-1}$, pod and stover yield increased significantly with supply of nitrogen and phosphorus in suitable combination of manures and fertilizer. This could be attributed to the sustained availability of nutrients throughout the growing season. The increased vegetative growth and 
the balanced C: $\mathrm{N}$ ratio might have increased the synthesis of carbohydrates, which ultimately promoted yield. The higher pod yield of groundnut might be due to cumulative effect of yield attributes such as number of pods, kernel pod ${ }^{-1}$ and weight of grains. These findings are in close conformity with those of Malligawad (2010).

Results showed (Table 1) that the increasing levels of Fe upto $10 \mathrm{~kg} \mathrm{ha}^{-1}$ significantly increased the no. of pods plant ${ }^{-1}(40.0$ and $15.3 \%)$, number of kernels pod $^{-1}$ (43.7 and $\left.20.1 \%\right)$, pod (20.7 and $14.3 \%$ ) and stover yield (11.9 and 5.2\%), on pooled mean basis over control and $5 \mathrm{~kg} \mathrm{Fe} \mathrm{ha-1}$, respectively but was found at par with $15 \mathrm{~kg} \mathrm{Fe} \mathrm{ha-1.} \mathrm{The} \mathrm{increase} \mathrm{in} \mathrm{no.} \mathrm{of}$ pods plant ${ }^{-1}$, no. of kernels pod ${ }^{-1}$, pod and stover yield may be attributed to the fact that favorable nutritional environment in rhizosphere and absorption of iron by plant leaves led to increased photosynthesis efficiency and production of assimilates as stated above. The higher translocation of photosynthates in reproductive structures resulted in increased yield attributes which led to the increased pod and stover yield of groundnut. The results of present investigation are in conformity with those of Umamaheswari and Singh (2002).

\section{Conclusion}

Application of poultry manure $3 t+1 / 2$ RDF and Fe levels upto $10 \mathrm{~kg} \mathrm{ha}^{-1}$ significantly increased the dry matter accumulation, branches plant ${ }^{-1}$, dry weight of nodules, leaf area index, no. of pods plant ${ }^{-1}$, no. of kernels pod ${ }^{-1}$, pod yield and stover yield of groundnut during both the years of study.

\section{References}

Akbari, K.N., Kanzaria, K.K., Vora, V.D., Sutaria, G.S., Padmini, D.R., 2011. Nutrient management practices for sustaining groundnut yield and soil productivity on sandy loam soils. Journal of Indian Society of Soil Science 56(3), 308-311.

DAC (Department of Agriculture and Cooperation), 2013. Annual Report 2012-13. New Delhi 11001, India.

Gomez, K.A., Gomez, A.A., 1989. Statistical Procedure for Agricultural Research. $2^{\text {nd }}$ Ed., IRRI. John Wiley and Sons, New York, Singapore.

Gupta, R.K., Kaushik, S., Sharma, P., Jain, V.K., 2003. Biofertilizers: An eco-friendly alternative to chemical fertilizers. Environmental Challenges of the $21^{\text {st }}$ Century, APH Publishing Corporation, New Delhi, 275-287.
Jackson, M.L., 1973. Soil chemical analysis, Prentice Hall of India Pvt. Ltd., New Delhi, 38-56.

Lindsay, W.L., Norvell, W.A., 1978. Development of a DTPA soil test for zinc, iron, manganese, and copper. Soil Science Society of America Journal 42, 421-428.

Malligawad Lokanath, H., 2010. Effect of organics on the productivity of groundnut and its residual effects on succeeding safflower under rainfed farming situations. $19^{\text {th }}$ World congress of soil science, Soil Solutions for a Changing World 1-6 th $^{\text {A }}$ August 2010, Brisbane, Australia.

Metson, A.J., 1956. Methods of chemical analysis for soil survey samples. New Zealand, D.S.I.R. Soil Bureau, Bull. 12, 208.

Olsen, S.R., Cole, C.V., Watanabe, F.S., Dean, L.A., 1954. Estimation of available phosphorus in soil by extraction with $\mathrm{NaHCO}_{3}$. Circular USDA, 939.

Priya, R.S., Chinnusamy, C., Manicaksundaram, P., Babu, C., 2013. A review on weed management in groundnut (Arachis hypogaea L.). International Journal of Agricultural Science and Research 3, 163-172.

Singh, A.L., 2004. Mineral nutrient requirement, their disorders and remedies in groundnut. Groundnut Research in India. 137-159.

Snell, F.D., Snell, C.J., 1959. Chlorometric method of analysis $3^{\text {rd }}$ Edn. II D. Var. Nostarand Co. Inc. Newyork.

Subbiah, B.V., Asija, G.C., 1956. A rapid procedure for the estimation of available nitrogen in soils. Current Science 25, 259-60.

Sumathi, V., Rao Koteswara, D.S., 2007. Effect of organic and inorganic sources of nitrogen with different irrigation schedules on growth and yield of sunflower (Helianthus annus). Indian Journal of Agronomy 52(4), 77-79.

Veeramani, P., Subrahmaniyan, K., 2011. Nutrient management for sustainable groundnut productivity in India-a review. International Journal of Engineering Science and Technology 3, 8138-8153.

Veeramani, P., Subrahmaniyan, K., Ganesaraja, V., 2012. Organic manure management on groundnut-A review. Wudpecker Journal of Agricultural Research 1(7), 238-243.

Umamaheswari, P., Singh, C.P., 2002. Influence of irrigation levels and micronutrients (Fe and $\mathrm{Zn}$ ) on yield and yield attributes of Rajmash (Phaseolus vulgaris L.). Legume Research 25(2), 121-123. 